This item was submitted to Loughborough's Research Repository by the author.

Items in Figshare are protected by copyright, with all rights reserved, unless otherwise indicated.

\title{
Youth organisations and the reproduction of nationalism in Britain: the role of Urdd Gobaith Cymru
}

\section{PLEASE CITE THE PUBLISHED VERSION}

http://dx.doi.org/10.1080/14649365.2016.1139166

\section{PUBLISHER}

(c) Taylor \& Francis

\section{VERSION}

AM (Accepted Manuscript)

\section{PUBLISHER STATEMENT}

This work is made available according to the conditions of the Creative Commons Attribution-NonCommercialNoDerivatives 4.0 International (CC BY-NC-ND 4.0) licence. Full details of this licence are available at: https://creativecommons.org/licenses/by-nc-nd/4.0/

\section{LICENCE}

CC BY-NC-ND 4.0

\section{REPOSITORY RECORD}

Jones, Rhys, Peter Merriman, and Sarah Mills. 2019. "Youth Organisations and the Reproduction of Nationalism in Britain: The Role of Urdd Gobaith Cymru". figshare. https://hdl.handle.net/2134/19369. 


\section{Youth organisations and the reproduction of nationalism in Britain: the role of Urdd Gobaith Cymru}

Rhys Jones, Department of Geography and Earth Sciences, Aberystwyth University Peter Merriman, Department of Geography and Earth Sciences, Aberystwyth University Sarah Mills, Department of Geography, Loughborough University

Accepted for publication in Social \& Cultural Geography on $28^{\text {th }}$ September 2015

\section{Introduction}

In this paper we examine the role played by youth organisations in shaping the national identities of young people in the UK. We argue that, in general, the role of youth organisations in shaping the individual and group identities of young people has been neglected. In particular, there has been a dearth of research on the key role played by youth organisations in shaping the cultural and political identities of youth in the various territories - or what are sometimes called the devolved nations - of the UK. This second area of neglect is particularly surprising, given the potential for youth organisations in these territories to reflect and help to promote national identities within them. Our aim in this paper is to begin to fill this gap by examining the role played by a key youth organisation in Wales - Urdd Gobaith Cymru (literally Wales’ Guild of Hope) - in reflecting and shaping Welsh national identities.

In doing so, this paper makes two contributions to existing debates in social, cultural and political geography. First, in relation to scholarship on the cultural and political geographies of the nation, the paper highlights how youth organisations imagine, represent and reproduce the nation. The paper importantly moves discussion away from hegemonic constructions of Britishness, a theme that has dominated the existing literature on youth organisations in the UK. Instead, we emphasize the connection between youth organisations and devolved identities and 'alternative' forms of nationalism (cf. Hopkins, 2007). Crucially, the paper demonstrates how the 
Urdd occupied the practical, but not necessarily neutral, 'middle' ground of an everyday nationalism, sitting between both 'hotter' and 'banal' expressions of nationalist politics in Wales. This discussion, as such, also contributes to burgeoning work on the cultural-political geographies of children and young people (Skelton, 2013).

Second, the paper demonstrates the importance of recognizing culturallinguistic identity as a crucial tenet of 'group-making' projects, emphasizing how language can bind the members of youth organisations (and by extension members of the nation) together. Most accounts of youth organisations focus on the 'groupness' of age classifications or religious denominations, whereas this unique case study of Urdd Gobaith Cymru highlights how language can become a key marker of group identity. This second contribution connects to ongoing debates in social and cultural geography on identity and belonging, specifically on the role of language in shaping cultural and political affiliations and practices (Valentine et al, 2008). The paper demonstrates how the Urdd's policies and membership reflected the changing linguistic geographies of Wales. More broadly, it demonstrates the diverse 'cultural politics' of youth organisations and their complex relationship to wider geographies of nationhood, identity and belonging.

\section{Nations, 'groupness' and the geographies of (devolved) youth organisations}

In broad terms, our paper is concerned with explicating the way in which young people are socialised into the nationalist 'group-making project' (Brubaker, 2004). For many years, social scientists have promoted a social constructivist view of the nation, arguing that nations and nationalism should be viewed as 'a "discursive 
formation”, a way of speaking that shapes our consciousness' (Calhoun, 1997, p. 3).

Brubaker (2004, p. 1) develops this argument by maintaining that

\begin{abstract}
Ethnicity, race, and nation should be conceptualized not as substances or things or entities or organisms or collective individuals - as the imagery of discrete, concrete, tangible, bounded, and enduring "groups" encourages us to do - but rather in relational, processual, dynamic, eventful, and disaggregated terms. This means thinking of ethnicity, race, and nation not in terms of substantial groups or entities but in terms of practical categories, situated actions, cultural idioms, cognitive schemas, discursive frames, organizational routines, institutional forms, political projects and contingent events.
\end{abstract}

The 'groupness' of nations is something, therefore, that needs to be forged through continual and iterative practice and explained by academics rather than being taken as ontological 'givens'. Group-making is a project that is based on a series of performances and events that are variously extraordinary (Ignatieff, 1993), banal (Billig, 1995) and everyday (Jones and Merriman, 2009) in character.

Nations, in this respect, are communities of people that are imagined through a series of nationalist discourses (Anderson, 1983), rather than being actual communities of people, which possess agency. Such an approach to the nation begs a series of questions about the authors of these discourses, the way in which they are communicated to, and subsequently consumed by, members of the nation. Doing so does not necessarily mean that we should fall into the trap of seeing a political and cultural elite as the only ones that have the power to shape nationalist discourse (e.g., Hobsbawm, 1983; Hroch, 1985). Attempts have been made to democratise the process whereby the 'groupness' of the nation is promoted (Jones, 2008). As many sociological studies have shown, everyday events, as well as being cast as examples that reflect the pre-existence of nationalist discourses and practices, are at one and the 
same time, producers of those selfsame discourses and practices. The act of sitting in the Welsh-speaking bar rather than the English-speaking lounge in a public house, choosing to sit as a group of Welsh speakers within an English-medium lecture, or defacing an English road sign because of its status as an affront to the Welsh national territory, are all examples of how ordinary individuals can contribute to the reproduction of nationalist discourse and practice; not merely as passive consumers but as active producers (Jones and Desforges, 2003; Jones and Merriman, 2009).

One key arena within this complex reproduction of nationalism that has been addressed is in relation to the youth of the nation. Much work has been carried out examining the significance of state education systems for translating the 'low cultures' of modern populations into the 'high culture' of the nation (Gellner, 1983; Zhao, 1998). As Scourfield and Davies (2005, p. 85) aptly put it, “children can be pivotal in the structuring of modern nation states” (see also Stephens, 1997). Particular academic subjects, especially History and Geography (Paasi, 1996), have been viewed as crucial providers of nationalist knowledges. In this work, attention has been focused on how school environments expose children and young people to a whole new range of experiences and knowledges, facilitating a shift in their culture, identity and world views (Jeffs and Smith, 2010). The danger with this work - and perhaps this is partly a reflection of the fact that it is the socialisation of the youth of the nation that is being studied here - is that it can almost reinforce a notion that the members of the nation are merely the passive consumers of nationalist discourses. It is important to note two observations here. First, as Benwell’s (2014, p. 53) recent study on nationalism in secondary schools in Argentina and the Falkland Islands demonstrates, teachers are not passive but can "negotiate geopolitical aspects of the curriculum that are central to national identity”. And second, children - as social and 
political actors (see Philo and Smith, 2003; Skelton, 2013) - have the potential to resist or, alternatively, be active contributors to the nationalist messages that they encounter within formal education (e.g. Scourfield and Davies, 2005; Scourfield et al, 2006). Nationalist discourse is inherently polyvocal in character.

At the same time, we need to remember that young people spend only a certain amount of their waking hours engaged in formal education and, as such, are exposed to and contribute to the 'group-making project' of the nation in numerous other ways. One key context for a great number of young people is their engagement with youth organisations of different types. Formal youth organisations emerged towards the end of the nineteenth century and, in Britain, were created and framed specifically along lines of religion, usually with separate gendered organisations for girls and boys - simultaneously constructing community cohesiveness within particular groups, and constructing and emphasizing ‘differences' along lines of gender and religion (e.g. Springhall, 1977; Tebbutt, 2012). Their emergence also echoed the formation of popular youth movements in a range of other European countries during the early twentieth century (Laquer, 1962; Stachura, 1981).

One important measure of the significance of youth movements is their scale as organisations. The Guides and the Scout Movement are currently the two largest uniformed youth organisations in the UK, possessing 550,000 and 400,000 members respectively in 2014. In addition to these familiar youth organisations, there are a range of other, more 'niche' organisations in the UK, such as the Woodcraft Folk, the Boys’ and Girls’ Brigades, Urdd Gobaith Cymru, as well as other more locally-based youth organisations (e.g. Prynn, 1983; Loeffler, 2006; Kyle, 2007; Tebbutt, 2012; Mills, 2014). While individually each of these may not possess the same levels of 
membership as the Guides and the Scouts, their collective impact on the lives of young people in the UK is substantial.

Additionally, the limited number of studies conducted to date on youth organisations also make a series of assertions about the qualitative impact of youth work on the lives of young people. Youth organisations have been deemed, first and foremost, to be engaged in a moral project; one which has sought to inculcate members with a series of principles and values (Kadish, 1995; Springhall, 1977; Wilkinson, 1969; Warren, 1986). At the same time, youth organisations have also often explicitly and sometimes implicitly - been involved in a second aim, which has revolved around the need to create more active citizen-subjects or more useful members of the nation. We witness these twin aims in the founding of the archetypal youth organisation in the UK, namely the Scouts. Baden-Powell, the founder of the Scout Movement, made clear these twin commitments when he published his Scouting for Boys in 1908 (Baden-Powell, 1908; Proctor, 2002). He was particularly concerned with the growing preponderance of idle, weak and potentially immoral young men. In addition to this moral concern was a related focus on the fact that these were, of course, young British men. The Scout movement, from the very outset, was concerned with the need to ensure that its members would fulfil their roles as responsible, active and useful members of the British nation and empire (Warren, 1986; Proctor, 2002; 2009).

The goals of youth organisations have, of course, evolved over the course of the twentieth century. The focus on empire and, indeed, nationalism may not be as overt today as it was for much of the twentieth century. Youth organisations have, increasingly, been enrolled into promoting a series of 'softer' life skills among young people, particularly those skills that enable young people to gain meangingful 
employment, as well as making active contributions to the communities in which they live (Jeffs and Smith, 2010). Youth organisations are, today, part of a broader neoliberal policy agenda that seeks to make young people useful to society (e.g. HMT and DSCF, 2007; Scottish Executive, 2007; WAG, 2007). They can be viewed as key contributors to a broader process through which young people are governmentalized. As individuals and as broader populations, young people are encouraged to act in particular ways, through direct guidance and, importantly, self-regulation (Foucault, 2002 [1970]; Merriman 2005; Gagen, 2015).

Particular mechanisms have been used to achieve these goals. Centrally, the role of outdoor education, nature and adventure has been seen by youth organisations as a significant part of their activities, connecting symbolic ideas of the nation with structured interactions with nature; particularly in relation to camping (Matless, 1995; 1998; Phillips, 1997; for the significance of camping, see Cupers, 2008; Kyle, 2007; Alexander, 2009). These camps are important events that allow a degree of 'mixing' of young people from different locations and provide an opportunity for members to acquire an understanding of the similarities that exist between them.

At the same time, the majority of activities engaged in by the members of youth organisations are locally based. Many of the weekly activities that Scouts have engaged with over the twentieth century, for instance, have been centred on carrying out good deeds in the locality in which they live. The Cub Scout Law - “A Cub Scout always does his best, thinks of others before himself and does a Good Turn every day” (quoted in Mills, 2013, p. 128) - highlights the close connection that is drawn between the Cub Scout and a localised morality, where each individual member of the organisation is supposed to give something back to the life of their local community on a daily basis. And yet, part of the power of prominent youth 
organisations such as the Scouts is the fact that they are able to inculcate a belief among members that they are part of something bigger; that the acts of charity that Cub Scouts are doing within their own neighbourhood are being replicated in other neighbourhoods throughout the nation. In this way, youth organisations, through the discourses they produce and the activities that they encourage, enable young people to bridge the divide between local and national communities: local activities are given additional meaning through their connections to a national framework of meaning and practice, while these local practices also help to constitute the national organisation (in a related context, see Jones and Fowler, 2007). It is likely too that the occasional international camps, rallies and jamborees that aim to facilitate direct connections between members of youth organisations at international and global scales - though relatively under examined (Vallory, 2012) - also help members to make additional sense of their place within these organisations, as national configurations of youth organisations are compared and contrasted with each other.

Reference to the good deeds carried out by Scouts in their locality begins to denote some of the significant if mundane ways in which young people are socialised into a youth movement. For instance, many youth movements have adopted uniforms and badges as a way of inculcating loyalty, shared identity and commitment among their members. The Scouting and Guiding movements have both had designated uniforms to help promote the group identity of members. Likewise, Urdd Gobaith Cymru, the youth organisation discussed in this paper, has made use of a threecoloured badge to signify the commitment of its members to Wales (green), humanity (red) and Christ (white). In some cases, badges are distributed and collected as material symbols of the kinds of skills and knowledges developed and acquired through practical activities (Mills, 2013: 129). 
Echoing research undertaken on the role of formal education in shaping the identities of young people, we also need to pay attention to the active role played by young people in the constitution of youth organisations, as well as the broader identities that they are associated with. Mills has shown how the Scouting movement has been continually re-defined and 'stretched' in different directions, whether in relation to gender, faith and ethnicity, and political ideals (Mills 2011a; 2011b; 2012). The major impetus in this whole process has come from the demands of members within (or, indeed, potential members of) the Scouting movement. In this respect, the Scouting movement has never solely and unproblematically reflected a singular Scouting ideal of 'good citizenship'. With its members pushing for a proliferation of definitions of good citizenship over the course of the twentieth century, so the Scouting movement has had to reflect upon and reshape its own identity as an organisation. Some demands have been accommodated in relatively straightforward ways, such as the need for a co-educational Scouting movement (Mills, 2011a) and demands to embrace religious difference (Mills, 2012). Others, such as those thrown up by the presence of a Communist Scout within the movement during the 1950s, did not lead to a process of accommodation but rather encouraged the Scout movement to re-emphasise its traditional commitments to the state and to Christianity (Mills, 2011b). The exact outcomes of these processes are, nonetheless, less important than the fact that they took place in the first place. They illustrate the contribution members of youth organisations make in reinforcing, as well as constituting, the cultural projects that those youth organisations espouse.

The above discussion begins to illustrate the contribution that youth organisations make to the lives of their members. One thing that is noticeable about the academic literature on youth organisations is that it has tended to focus solely on 
those organisations associated with the 'group-making project' of British nationalism. Very little work has been conducted on some of the smaller, yet still significant, youth organisations that have sought either explicitly or implicitly to contest the British nation-building project (though see Prynn, 1983; Loeffler, 2006; Mills, 2014). The impact of devolution on the UK has only served to heighten the need for a more nuanced and thorough account of the sometimes contrasting roles played by youth organisations in shaping the identities of its young people. To what extent have distinctive youth organisations in the various territories of the UK helped to shape a group identity among their members that is sometimes at odds with notions of Britishness? Answering this question would not only help us to understand the direct impact of youth organisations on the lives of young people in the various territories of the UK but would also begin to show the broader, more indirect, influence that these organisations have had on the 'group-making processes' taking place in these territories; as these organisations have sought to shape political debate more broadly within their nations. Focusing on such themes would also allow an examination of the impact that such organisations have had on their former members, some of whom have graduated to play key roles within devolved politics, government and culture.

Our aim in this paper is to begin to contribute to this agenda by examining the impact that Urdd Gobaith Cymru has had on the identities of young people in Wales. The following section discusses how the Urdd sought to promote a version of Welsh nationalism among Welsh youth, before proceeding to elaborate on how this vision was tested and stretched in different directions from the 1950s onwards. Brief conclusions follow.

\section{Urdd Gobaith Cymru and the contestation of Britishness}


Urdd Gobaith Cymru was formed in 1922 by Sir Ifan ab Owen Edwards as a way of steering 'Welsh children and adolescents...in the direction of a Welsh citizenship’ (Löffler, 2006, p. 82). The seed sown by Edwards quickly took root. Membership figures grew rapidly during the 1920s and 1930s and have remained at around 50,000 since the 1950s. The Urdd has been successful in reproducing different aspects of a Welsh 'national culture’ amongst the nation’s youth. It has encouraged them to purchase Welsh-medium books and periodicals, and during the 1980s 46,000 magazines were distributed to Welsh school-children, containing a variety of historic and geographic representations of Wales. The Urdd promotes an annual Youth Eisteddfod in which some 15,000 young people engage in Welsh cultural practices (e.g., singing, reciting, folk dancing). Outdoor activities are actively promoted, reflecting its founder's belief in the benefits of physical exercise (Edwards, 1943). Summer camps have been central to the Urdd's activites, and by the 1970 s over 12,000 individuals were attending mixed-sex camps in its residential centres. Finally, the Urdd has always possessed a strong humanitarian and internationalist ethos. In 1930, for instance, the Urdd designated May as a month of 'goodwill' and organised a 'pererindod' (pilgrimage) for some of its members to the League of Nations in Geneva (Griffith, 1972, vol.1, p. 102). In the post-WWII period, the Urdd also organised international summer camps in Wales, drawing in visitors from a range of countries (Griffith, 1972, vol.2, pp. 67-71).

We draw on archival sources as a means of outlining different aspects of the Urdd's role in promoting a Welsh 'group making project' in the period after the Second World War, one that was promoted in opposition - sometimes explicitly and at other times more implicitly - to the group identities associated with Britishness (see Conversi, 1995). Working on the archives of the Urdd has posed certain difficulties. 
While all archives are partial and incomplete, it is evident that those of voluntary organisations are even more so. The lack of funding available to employ an archivist, the lack of space available to store written material and, usually, the overwhelming focus among the organisation's employees on securing its organisation's short- and medium-term future rather than reflecting on its short- or long-term past, means that the archives of voluntary organisations are often limited in scope. This was certainly the case with Urdd Gobaith Cymru’s archive. Even though the material was deposited in the National Library of Wales between 1989 and 1997 - and therefore benefited from being archived in a thorough and professional manner - it is evident that the archive itself is limited in extent. For instance, while there is interesting information available on the summer camps held in numerous locations throughout Wales between 1940 and 1995, only a limited number of years are reflected in this section of the archive. Very little information exists, for example, for the camps held during the 1970s and 1980s.

The problems associated with the Urdd's archive are exacerbated by the fact that the Urdd is, in many ways, made up of constituent local branches; aelwydydd (hearths) and adrannau (units). These are the Urdd groups that meet on a regular basis within particular schools or communities. The fact that the Urdd is organised in such a way means that a vast amount of archival material that relates to the Urdd is held in, or has been lost from, local record offices, school offices or, indeed, filing cabinets of a whole host of Urdd leaders within various localities. Painting a comprehensive picture of the Urdd's activities through archival research is, therefore, a painstaking and sometimes frustrating enterprise. Collecting the oral histories of former members could well help to address some of these limitations in the future. 
Despite these difficulties, a range of material was collected, which illustrated different aspects of the Urdd's role within the Welsh group-making project. This material was subject to textual analysis, in which an effort was made to illustrate the common themes arising within them, as well as any inconsistencies. The material was coded in relation to codes that were internal (source-based) and external (researcher-based) to the texts. On a linguistic note, the majority of the material gleaned from the Urdd's archives are in Welsh and have been translated by us into English. Doing so, obviously, raises issues of consistency and we sought to minimise the impact of this issue by ensuring that the translations were as faithful to the original as possible. We would, ideally, have liked to include the Welsh original text and the English translation but we have not been able to do so for reasons of space.

Our empirical discussion in this paper focuses on two key themes. First, we discuss the nationalist discourses and practices promoted by the Urdd since its formation in 1922 (Loeffler, 2006). Second, we examine some of the material from the period between the 1950s and 1970s, a time of rapid social, cultural and political change in Wales; for instance, with the decline in the overall numbers and percentages of the population of Wales being able to speak Welsh, and a growing prominence of a more radical kind of Welsh nationalism (Johnes, 2012). Focusing on these issues enables us to show how the Urdd's cultural and political project was increasingly contested and challenged from inside and outside the organisation.

\section{The role of the Urdd: a discourse of citizenship and nationalism}

The significant role played by the Urdd in shaping the identities of the young people of Wales was made clear from the very founding of the movement in 1922. Writing in Cymru'r Plant (Children's Wales), the Welsh-medium children's 
periodical founded by his father in 1882, Sir Ifan ab Owen Edwards outlined his vision for Urdd Gobaith Cymru:

\begin{abstract}
What shall we do, the children of Wales, to keep the Welsh language alive?...What shall we do, the children of Wales, who love Little Wales, our own country? We have to do something since we are our country's hope. What if we should join together to decide to do everything that can help our nation? We will found a new Guild, a try to get every Welsh boy and girl under eighteen to join it, and we shall call our Guild 'LITTLE WALES' GUILD OF HOPE’ (quoted in Griffith, 1972, vol.1, p. 32, original emphasis).
\end{abstract}

A number of things are apparent in the above quote. First, it is clear that linguistic and nationalistic reasons both played a significant part in Ifan ab Owen Edwards' decision to form the Urdd. There was a need for prospective members to 'keep the Welsh language alive' and to ‘do everything that can help our nation'. The quote illustrates the strong connection that has existed between a more 'ethnic' version of Welsh nationalism and the ability to speak the Welsh language, one which has been contested by non-Welsh speaking activists and authors (e.g. Smith, 1984; more broadly, see Anderson, 1983). Second, there is an interesting attempt made by Edwards to align himself closely with his target audience of young Welsh people. He asks 'What shall we do...', emphasising the common and united aims of the Urdd, and its prospective members (cf. Billig, 1995). Thirdly, while Edwards drew some of the inspiration for the founding of the Urdd from the success of other popular youth movements of the time - namely the Boy Scouts and the Girl Guides - it is significant that his new organization was imagined as a co-educational movement from the outset, in contradistinction to these other two organisations. 
A more detailed sense of the vision put in place for the movement can be gleaned from the rules of membership set out by Edwards in the same article.

Members were expected to:

1) Speak Welsh to every other Welsh-speaking child in Wales, particularly with every one who is a member of the Urdd.

2) Read and buy Welsh books.

3) Sing Welsh songs.

4) Play at all times in Welsh.

5) Never deny that we are Welsh, nor betray our country under any circumstance.

6) View all Welsh people, even if they are poor and in rags, as friends to us, and do our best for them.

7) Wear the [Urdd's] badge as often as possible (Griffith, 1972, vol.1, p. 33).

There is an attempt here to map out some of the key cultural characteristics of Welsh nationalism, namely the Welsh language, Welsh literature and traditions of Welsh singing. At the same time, the vision espoused by Edwards is one that is based on a pride in ones nation's and a concomitant desire to protect it from external and internal threats, most notably from what was said to be an 'English hailstorm that is sweeping across our country’ (ibid). Finally, and notably distinct from the vision promoted by similar youth movements such as the Scouts and the Guides, the rules reflect a desire for the Urdd to play a prominent role in promoting egalitarian and humanitarian ideals. In these series of statements, we see how Edwards sought to position the Urdd as a key organisation for promoting Welshness among Welsh youth. It was a vision that was based on the notion that: the condition of a Welsh nation's youth was a good indicator of its future trajectory (cf. Zhao, 1998); the Welsh nation was being defined in opposition to England and Englishness (Conversi, 1995); and the Welsh nation was intimately connected to the Welsh language and associated cultural forms (Jones and Fowler, 2007). 
The valuable role played by the Urdd in promoting a Welsh identity among the youth of Wales was recognised by many cultural leaders within Wales. The renowned Welsh novelist Islwyn Ffowc Elis, for instance, wrote in the early 1970s about the major contribution made by the Urdd to sustaining the Welsh language and culture. He argued that the Urdd had helped to create:

A new Wales. Not a free Wales, but a Wales that can become free; not a Welsh Wales, but a Wales in which the Welsh language is raising its head. And here, in this corner of the world, instead of a nation that is ready to die there is a nation that is determined to live. $^{1}$

For many members, the highlight of their association with the Urdd was their attendance at a summer camp; either at Llangrannog or Borth on the Ceredigion coast, Cricieth on the Llyn Peninsula or Glan-llyn on the shore of Lake Tegid near Bala, Gwynedd. Feedback from attendees of the camps illustrates the impact that the experience had on their attitude towards the Urdd as an organisation and towards its broader political and linguistic project. ${ }^{2}$ The leaders of the Urdd were also aware of the role played by the summer camps in enthusing and inspiring members:

[Members] not only receive a week of enjoyment in the Urdd camps but also a week that is full of inspiration. There is no doubting any more that the work undertaken in these camps is contributing towards the creation of a generation of Welsh and Christian citizens. ${ }^{3}$

Many aspects of these camps would be familiar to a former Scout or Guide, involving trekking, boating, kayaking, swimming and singing around a campfire. And yet, there is no doubting the additional cultural, linguistic and religious elements that were a feature of the Urdd's camps. One satisfied camper, for instance, wrote in 
1957 of the pleasure he experienced partaking in cultural evenings and folk dancing organised in the Glan-Llyn camp. ${ }^{4}$ Details of the activities undertaken in the camps demonstrate the role played by religious activities, on Sundays but also, to a lesser extent, at the start and end of every day. ${ }^{5}$

An additional significance of the camps was that they often provided one of the first opportunities young Welsh people had of interacting with Welsh speakers from other parts of Wales. Prior to the advent of the Welsh-medium national radio station, Radio Cymru, in 1977, and the Welsh-medium national television station, S4C, in 1982, Welsh speakers in different parts of Wales would have had limited opportunities to hear different Welsh accents and colloqualisms. This is why the Urdd's summer camps, bringing together youths from different parts of Wales, were so significant (see also Baker, 1998; Tilly, 1975; Jones and Desforges, 2003). A flavour of this new linguistic experience is given in a play performed in the Llangrannog summer camp in 1940-41. As well as noting in a comedic way the number of difficulties in communication that could ensue from this mixing, the play also noted the cultural value associated with the experience, stating that:

There are nearly one hundred and fifty girls here from every part of Wales - from Holyhead to Cardiff - and every one speaking Welsh and loving Wales. Children from the Rhondda valley sleeping in the same cabin as children from Caernarfonshire, and children from Carmarthenshire sharing their [food] parcels with children from Meirionethsire, and everyone happy all day. ${ }^{6}$

While the summer camps were viewed as the highpoint of the Urdd's calendar - and while the Urdd's leaders were aware of and grateful for this significance - it is evident that the organisation's leaders were also keen to stress the importance of members' weekly activities in local branches. These were viewed as the backbone of 
the organisation, providing regular contact with the discourses, values, practices and members of the Urdd (Jones and Merriman, 2009; Mills, 2013). An article in Cymru'r Plant in 1952 emphasized the importance of the weekly meetings, over and above other activities sponsored by the Urdd:

Do you know what is the most important work within the Urdd? Not the National Eisteddfod, not the large camps, nor the journeys to foreign countries; no, not any of these but rather the regular and hardworking meetings of the Adrannau. If Adrannau do not work and meet regularly, the Urdd's work can never be a success (Cymru'r Plant, 1952a, p. 342).

And yet, it would be unwise to draw too strong a distinction between the significance of summer camps and the role of local branches. The Urdd's leaders highlighted how the one set of activities could reinforce the other. Preparing for and reflecting on the experiences of attending summer camps, in particular, was viewed as an important way to inspire members in Adrannau during the long nights of a Welsh winter (Cymru’r Plant, 1952b, p. 378)!

In undertaking these different activities the Urdd's leaders drew upon and reinforced distinctive geographical imaginations of Wales. As Gruffudd and others have shown historic interpretations of Welsh politics and culture have often emphasized certain key places, regions and landscapes above others (Gruffudd 1994; 1995; see also Jones and Fowler, 2007). The Urdd, for much of its existence, has promoted a vision of Welshness that is distinctively rural in nature. Rural areas of the north-west and west Wales were seen as the protective heartlands of a threatened and declining language (Gruffudd 1994). It is no surprise, therefore, that one of the Urdd's main camps was located outside Bala in north-west Wales, and the organisation actively referred to the area as a 'truly' Welsh place (Cymru'r Plant, 1950c). As well 
as reflecting a dominant regional and rural representation of Welshness, many within the Urdd viewed the experience of attending these camps - in specific parts of Wales - as a means of enabling young people to reach higher states of Welshness as both individuals and groups. It was not just that young people were visiting summer camps that was important, but also the fact that these visits took place in areas of Wales that were - due to their linguistic and cultural makeup - seen to be more Welsh in character than other, more urban, industralised, and anglicised areas.

Finally, the Urdd gained much publicity, as well as an ability to shape the activities and identities of its members, as a result of its key publications including Cymru'r Plant and (for slightly older members) Yr Aelwyd. Cymru'r Plant was viewed as being particularly important because of its status as the first nondenominational children's magazine in Wales. Its significance for the movement was made clear in an issue of the magazine published on the sixtieth anniversary of its launch:

[Cymru'r Plant] is the monthly magazine of the children of Wales, and Wales has been of no more dire a need of it than it is today. It would be an outrage if it were to disappear now while we are striving to keep the Welsh language alive; and we cannot succeed if we do not all of us try our hardest to help it (Cymru'r Plant, 1951a, p. 343).

The article went on to encourage children and schools to subscribe to the magazine, as well as encouraging teachers and other adults to write articles to be published in its pages.

Negotiating a new Welsh nation: the role of the Urdd between the 1950s and 1970s 
While the above evidence testifies to the twin contributions made by the Urdd in promoting both the Welsh language and nation, it is clear that the facets of this group-making project shifted over time. The period between the 1950s and 1970s, especially, was characterised by a degree of reflection and soulsearching about the appropriate role to be played by the Urdd within a Wales that was undergoing considerable social change; most notably in relation to the secularisation of Welsh society, changing understandings of childhood and adolescence, a decline in the vitality of the Welsh language, and a related increase in a more combative form of Welsh nationalism. It is unsurprising that these developments led to considerable debate within the leadership and membership of the Urdd given that it was - and still is - a youth organisation possessing strong links with religion, one which has sought to support the Welsh language and nation, and one which has had a sometimes tense relationship with other Welsh nationalist movements.

One key area of debate revolved around the secularisation of Welsh society, which was a trend that was bound to have had a large impact on an organisation that had a longstanding connection to Christianity. In a Commission on the Life and Work of the Urdd, conducted during the 1970s, members were asked to reflect on the role played by the organisation and its relevance to Welsh society, politics and culture. One set of questions revolved around the issue of the Urdd Promise, in which members are asked to profess their faithfulness to Wales, their fellow-man and Christ. While the vast majority of respondents affirmed the relevance of the Promise, some drew attention to the fact that its third component could act as sticking point for some potential members ' $(a)$ in the secular society that we live in today (b) for members that adhere to other religions'. The Commission sought a way out of this conundrum by stating that the Promise should be viewed more as an 'aim to aspire to' and that the 
'important thing is acting in accordance with the Promise, and that members should not be expected to accept the Promise formally, as they would when swearing an oath'. ${ }^{7}$ In many respects, these kinds of debate echo similar ones that have taken place in other youth movements, as they have sought to accommodate religious difference within their membership (see Mills, 2012).

The changing linguistic geographies of Wales also impacted on the kind of message, and the kinds of activities, that the Urdd could promote. Wales was by no means monoglot Welsh or even wholly bilingual when the Urdd was formed in 1922, but there is a sense that it was an organisation that was dealing with a Welsh population for whom the Welsh language was a familiar aspect of everyday life. The situation had changed somewhat by the 1950s and 1960s, with a marked decline having taken place in the numbers of Welsh speakers. It was this decline that led the noted Welsh academic Saunders Lewis to write his famous public lecture on the Fate of the Language, which aired on the BBC in 1962 (Lewis, 1962). While this has been viewed as an inspiration for a more radical kind of linguistic and nationalistic politics in Wales (see below), it also reflects the existence of a new linguistic reality in Wales; a Wales in which there were more children and adolescents who were classified as Welsh learners (individuals who did not come from Welsh-speaking backgrounds but who wanted to learn the language) and non-Welsh speakers.

Evidence from the 1950s onwards demonstrates the way in which the Urdd grappled with people who fitted into the new linguistic category of the Welsh learner. The Urdd recognised the fact that it now had to accommodate Welsh learners within its ranks and it made an effort to articulate clearly the linguistic duties that were to be discharged by these individuals. In an article that appeared in Cymru'r Plant in 1952 
(the year of the thirtieth anniversary of the founding of the Urdd), the responsibilities of learners were clearly delineated:

You might ask, 'What about these children who cannot speak Welsh?'

The answer is that they will be expected to promise to learn Welsh and, if they do not honour this promise, they can be barred from being members (Cymru'r Plant, 1952c, p. 182, original emphasis).

Such an answer indicates the official policy of the Urdd on the status of learners; they would be expected to learn Welsh as a mark of their commitment to the Urdd, the Welsh language and the Welsh nation. And yet, such a bald statement masks the often difficult decisions that the staff and volunteers of the Urdd - as well as the members themselves - had to make about the linguistic competence or otherwise of current or prospective members. In a nutshell, these kinds of difficulties and contradictions revolved around deciding on when someone's status changed from being a non-Welsh speaker to being a learner to being a fluent speaker of Welsh. The following quote from a letter sent by Gwennant Davies, the national organiser of the Urdd's camps, to a teacher in a Porthcawl secondary school in 1955 gives a flavour of these more subtle kinds of decisions:

A little word in relation to [person A's] application for a place in Llangrannog. The two weeks for which she has applied - that is week 5 and week 4 - are, in fact, Welsh Weeks...I wonder whether she is Welsh enough to feel comfortable in a Welsh camp? ${ }^{8}$

In making the distinction between camps for fluent Welsh speakers and camps for Welsh learners (i.e. during weeks that were not 'Welsh weeks'), the above quote testifies to the difficulties in ascribing a linguistic identity (Anderson, 1983); both in 
terms of how individuals self-designated their own identity but also in the context of the Urdd's external designation of the identities of its members. In a broader context, it also testifies to the way in which the broader aims of the Urdd could be complicated and qualified by the practices of its workers and members.

In general terms, however, much was made of the positive impact that the Urdd had on the lives and identities of learners. Gwennant Davies, again, wrote to a teacher at Maesteg Grammar School in South Wales in 1957, asking for feedback on the impact that a camp including individuals with a variety of Welsh-language abilities at Llangrannog had had on some of her pupils, who happened to be learners. The teacher replied that:

The two pupils... have been faithful members of the Urdd from the beginning, and have shown a special desire to learn Welsh. They were very keen to mingle with the Welsh-speakers in the camp and, according to what they have said, the interaction was of a great help and inspiration to them. They do not hear any Welsh at home and going into the middle of children of their age and hearing them speak the old language was a means to strengthen their desire to practice Welsh themselves. I've already seen that they are readier to speak Welsh to me than they were. ${ }^{9}$

We see here how the experience of attending a camp containing individuals of mixed language ability could impact positively on the linguistic abilities - and possibly the broader identities - of Welsh learners.

Some of the articles published in Cymru'r Plant also sought to highlight the positive contributions that learners could make to the Urdd. A set of fictional stories related the experiences of Alec, ‘an English speaker from Glamorgan’, with the Urdd. One account relates his positive experience of the Urdd's athletics event, while another notes his excursion to the Museum of Welsh Life in St Fagan, near Cardiff (Cymru'r Plant, 1950a, pp. 216-7; Cymru'r Plant, 1950b, pp. 256-7). What is 
significant about these stories is the way in which they relate the positive impact that a Welsh learner, such as Alec, could have on other Welsh speakers within the movement. In the story that recalls Alec's experience of competing in the Urdd's athletics event, it is noted that the other Welsh speakers wish Alec well using a Welsh chant that they themselves had composed:

Good luck tomorrow,

To Alec the runner,

To Alec the jumper,

To Alec the learner,

Our very own Alec (Cymru’r Plant, 1950a, p. 217)!

The above quote is important since it shows the strong connection that existed between Alec as a learner and the majority of Welsh speakers within that local branch of the Urdd, and within the broader organisation. A learner, 'our very own Alec', was not viewed as a problem but rather as someone who could enrich the Urdd as an organisation.

Another major development that impacted on the Urdd's activities during the 1960s and the 1970s was the emergence of a more active and radical form of Welsh nationalism, centred on the activities of students and young professionals (Jones and Fowler, 2008; Phillips, 2005). The emergence of this type of nationalism brought into question the more conservative form of identity promotion that had been traditionally espoused by the Urdd. The cause celebre, which helped to highlight the contradictions between these different interpretations of Welsh nationalism, was the investiture of Charles Windsor as Prince of Wales in Caernarfon castle in 1969. The Urdd's ruling council was divided on whether to accept the invitation to attend the investiture. Those who advocated attending were fearful of the consequences of not attending on the Urdd's public sources of funding and its reputation among the Welsh 
and British establishment. Others on the council sought to use a lack of attendance of the investiture by the Urdd as a means of demonstrating its role as a key Welsh nationalist organisation. The upshot of the debate was a decision to send a small delegation of Urdd members to the investiture - a decision that was rescinded following a public outcry - and a subsequent invitation to Prince Charles to attend the Urdd Eisteddfod held in 1969 in Aberystwyth (Jones, 2010; Ellis, 2008, pp. 200-204).

The event illustrates some of the difficulties facing the Urdd during the 1960s and 1970s as it sought to chart a course through the turbulent currents of Welsh nationalism. Should it be a relatively neutral linguistic movement or should it view itself as an overtly nationalist movement, part of the widespread upsurge in a more radical form of Welsh nationalism, which characterised the 1960s and 1970s. It is significant that some sought to highlight the valuable alternative role played by the Urdd in contributing to Welsh nationalist debate and practice, as the following contribution made by R. Alun Evans, as part of the Commission on the Life and Work of Urdd Gobaith Cymru, shows:

The Urdd is in the middle of the battle for the language. It hasn't the time to march. It is too busy publishing magazines to protest. The Urdd is in the middle of the battle for bilingualism and is too busy, through its voluntary workers (the lifeblood of any movement) working night after night to generate interest among non-Welsh speakers in the best aspects of the life of the nation...At the same time as the regular idealising, the Urdd is working in practical ways: working not shouting; providing not demolishing; giving not disrupting. ${ }^{10}$

The quote here gives a passionate defence of the practical form of nationalism espoused by the Urdd. The Urdd may not have been heavily involved in the 'hotter' kinds of nationalism (Ignatieff, 1995) being promoted by organisations such as the Welsh Language Society during the 1960s and 1970s but they were playing a key role 
in the everyday encounters that young people in Wales were having with the Welsh language. There is a clear sense of a banal nationalism (Billig, 1995) being promoted by the Urdd, but also one that was tied in implicit ways to the 'hotter' varieties of nationalism being practised in Wales at the time. These everyday configurations of Welsh nationalism - ones that blurred the boundaries between banal and hot forms of nationalism (see Jones and Merriman, 2009) - could appear in many contexts; children reading about Welsh historic heroes on the pages of Cymru'r Plant or singing traditional and sometimes patriotic Welsh songs in summer camps. In all these we witness a blurring of the division between hot and more banal forms of nationalism, and the Urdd's role in promoting this.

In the period between the 1950s and the 1970s, the Urdd was involved in a final set of more geographical tensions; ones which revolved around contested geographical imaginations of Welshness. Many articles in Cymru'r Plant during this period still promoted the kinds of geographical imaginations that characterised the interwar period, namely imaginations that placed a considerable value on the north and west of the country. One article, published in March 1950, encouraged the members of the Urdd to use Wales’ patron saint day (1 March) as an inspiration to think about 'Wales, our land'. It is significant, however, that the Wales envisaged within the article was solely focused on its northern and western parts. It exhorts the Urdd's members as follows:

But, on this St David's day, I would like you in particular to think about the land of Wales. We all know the danger of losing our language; but how many of us realise that we can also lose our land, and truly, we are continually losing large tracts of it. When an English Holiday Camp is placed on Welsh land, that land is lost to Wales; when a military camp is placed on Welsh land, that land is lost in the same way (Cymru'r Plant 1950c, p. 95; see also Gruffudd, 2010). 
We see, here, how the Urdd was becoming embroiled in a key area of nationalist debate; namely the ability of Wales as a country to control its own land and resources. Further contributions to this broad debate appeared in the pages of Cymru'r Plant in relation to that most contentious of Welsh resources: water. An article appeared in November 1951, under the title 'The lakes whose water runs to England'. The article sought to use the historic example of the drowning of the Llanwddyn valley in north-east Wales as a means of exhorting the members of the Urdd to guard against similar plans to build Welsh reservoirs, which would service English cities, in the future (Cymru'r Plant, 1951b). The significance of Welsh land, and particularly that of rural Wales, was also emphasised in subtler ways, such as in the case of the fictional story of Marged, a Welsh-speaking girl who had lived the majority of her life in London, but who returned to live on the family farm once her father had been appointed to a post in Wales. The story ends with Marged eulogising about the quality of life associated with living in rural Wales: 'Isn't it heavenly in the country? Who would live in town if they could live in the countryside, especially the Welsh countryside?' (Cymru’r Plant, 1950d, p. 51).

While there is, therefore, a greater degree of continuity between the interwar and postwar periods in relation to the geographical imaginations of Welshness, there is still a sense in which some leaders within the Urdd were concerned about the impact that such as skewed geographical imagination could have on members and perhaps more importantly - prospective members in the more urban locations in the south-east of the country. In the Urdd's annual report for 1950, it was noted that there was a need for an Urdd camp to be located in the south and east of the country, 'within reach of the thousands of members who are in danger of losing their Welsh 
heritage altogether'. ${ }^{11}$ We witness here an early recognition of the need for the Urdd to cater for potential members from different parts of the country, a recognition that culminated in the Urdd opening its first urban camp in Cardiff Bay in 2004, five years after the creation of the National Assembly for Wales (Taylor,1993).

\section{Conclusions}

Our aim in this paper has been to discuss the significance of youth organisations for the 'group-making project' associated with nationalism. In particular, we have sought to fill what seems at first to be merely an empirical gap in the literature on youth organisations; by examining the role played by a prominent youth organisation that was set up in opposition to a British nation-building project. We have witnessed clear evidence of the role played by the Urdd in seeking to promote a particular vision of Welshness; one which was based on an ability to speak Welsh, as well as a being based on a commitment to Wales as a nation. We also elaborated on the various mechanisms used by the Urdd in order to achieve these goals, and also demonstrated how the organisation reacted to some of the major challenges that it faced in the period between the 1950s and the 1970s. Some of the major challenges included the decline in Welsh-language speakers, the growing radicalisation of Welsh nationalist politics and the changing geographic imaginations of Welshness.

And yet, what we have presented here represents more that an attempt to plug an empirical gap. What we have shown is that even though most youth organisations have possessed similarities, such as the emphasis that they have traditionally placed on camps, uniforms and badges, as well as a desire to improve the moral qualities of their members, we must also be mindful of the marked differences that have existed 
between them. The Urdd, for instance, has possessed a series of distinctive aspects that have marked it out from other youth organisations, especially its emphasis on promoting the Welsh language and its associated culture as part of its various activities. While it would be a mistake to suggest that other youth organisations in the UK have not been concerned with cultural issues - defined in its broadest sense - it is clear that the engagement of the Urdd with its members has been explicitly and overtly centred on such issues. The exhortations contained within the pages of Cymru'r Plant concerning the need for Welsh children and young people to buy Welsh books and magazines, to speak Welsh to all other Welsh speakers, to learn about Welsh historical and literary 'heroes' all testify to the cultural projects that have been at the heart of the Urdd's activities. Even when the Urdd's members ventured to the summer camps in order to enjoy living and playing in the Welsh countryside - for what some might say was a welcome break from the cultural activities that marked their usual engagement with the organisation - they were still encouraged to do so in a way that would reinforce their understanding of, and commitment to, the Welsh language and culture. In this context, we need to develop a greater appreciation of the similarities and differences between the aims and activities of different youth organisations as they have borrowed and amended ideas, one from another.

The other broader significance of this paper, of course, relates to understandings of Britishness. There has been much academic, political and popular discussion concerning the current and future trajectories of Britishness, not least in relation to devolution and the recent vote on independence in Scotland, and the ongoing debates about the contours of a multicultural Britain. The themes discussed in this paper show how youth organisations are not innocent bystanders in these kinds of political and constitutional developments. Youth organisations reflect the changing 
contours of various group-making projects, such as when the Urdd became slightly more radicalised in reaction to the broader currents of a Welsh linguistic nationalism during the 1960s and 1970s. At the same time, youth organisations can also become active contributors to nationalist group-making projects, not just for their young members but also in the context of the adult identities of their former members. While we have provided an historic account of this connection between youth organisations and group identity, it is clear that such connections are still considered to be important; by youth organisations and the various governments of the UK alike. But, of course, there is the potential now for devolved governments to use youth organisations as a way of promoting new kinds of national communities, often in opposition to Britishness. Even those youth movements that operate on a British scale tailor their activities to a certain extent in order to appeal to the new devolved contexts within which they now operate. Governments and youth organisations in the different territories of the UK are aware of the potential contribution that youth organisations have in helping to shape the identities of young people. It is now time for academics to realise the significance of youth organisations in shaping different kinds of territorial identity. Youth organisations are likely to feature for the foreseeable future as an important terrain over which ideas of group identity are negotiated in a devolved UK and it behoves us as social scientists to give them the attention they deserve. 


\section{References}

Alexander, K. (2009). Similarity and difference at Girl Guide Camps in England, Canada and India. In N. Block and T. Proctor (Eds.), Scouting frontiers: Youth and the Scout Movement's first century (104-118). Cambridge: Cambridge Scholars Publishing.

Baden-Powell, R. (1908). Scouting for Boys. London: Horace Cox.

Baker, A.R.H. (1998). Military service and migration in nineteenth-century France: some evidence from Loir-et-Cher. Transactions of the Institute of British Geographers, 23, 193-206.

Benwell, M. (2014). From the banal to the blatant: Expressions of nationalism in secondary schools in Argentina and the Falkland Islands. Geoforum, 52, 51-60.

Billig, M. (1995).Banal nationalism. London: Sage.

Brubaker, R. (2004). Ethnicity without groups. Cambridge, MA: Harvard University Press.

Conversi, D. (1995). Reassessing current theories of nationalism: nationalism as boundary maintenance and creation. In J. Agnew (Ed.) Political geography: a Reader (325-36). London: Arnold.

Cupers, K. (2008). Governing through nature: camps and youth movements in interwar Germany and the United States. Cultural Geographies, 15, 173-205.

Cymru’r Plant (1950a). Alex IV, hanes Alec, Sais o Sir Forgannwg. June, 216-17.

Cymru’r Plant (1950b). Alex V, hanes Alec, Sais o Sir Forgannwg. July, 256-57.

Cymru’r Plant (1950c). Cymru, ein gwlad. March, 95.

Cymru’r Plant (1950d). Ar gaeau Penybryn. February, 51.

Cymru’r Plant (1951a). Cymru’r Plant yn 60 oed. October, 343.

Cymru’r Plant (1951b). Y llyn y rhed ei ddwr i Loegr. November, 375-77. 
Cymru’r Plant (1952a). Cronicl yr adrannau. October, 342.

Cymru'r Plant (1952b). Cronicl yr adrannau. November, 378.

Cymru'r Plant (1952c). Cychwyn cyfnod newydd yn hanes yr Urdd. Trefn newydd aelodaeth flynyddol yr adrannau. June, 182.

Edwards, I.O. (1943). Yr Urdd 1922-43. Aberystwyth: Cwmni Urdd Gobaith Cymru.

Ellis, J.S. (2008). Investiture: Royal ceremony and national identity in Wales, 19111969. Cardiff: University of Wales Press.

Foucault, M. (2002 [1970]) The order of things: An archaeology of the human sciences. Abingdon: Routledge.

Gagen, E. (2015) 'Governing emotions: citizenship, neuroscience and the education of youth', Transactions of the Institute of British Geographers 40: 140-52.

Gellner, E. (1983). Nations and nationalism. Oxford: Blackwell.

Griffith, R.E. (1972). Urdd Gobaith Cymru vol. 1, 1922-45. Aberystwyth: Cwmni Urdd Gobaith Cymru.

Griffith, R.E. (1972). Urdd Gobaith Cymru vol. 2, 1946-60. Aberystwyth: Cwmni Urdd Gobaith Cymru.

Gruffudd, P. (1994). Back to the land: historiography, rurality and the nation in interwar Wales. Transactions of the Institute of British Geographers, 19. 6177.

Gruffudd, P. (1995). Remaking Wales: nation-building and the geographical imagination. Political Geography, 14, 219-39.

Gruffudd, P. (2010). The battle of Butlin's: vulgarity and virtue on the North Wales Coast 1939-49. Rural History, 21, 75-95.

Hammond, M. (2007/2008). Cross-community youth work training in a divided and contested society. Youth and Policy, 97/98, 47-65 
Harland, K. (2009) From conflict to peacebuilding: reflections and descriptions of youth work practice in the contested spaces of Northern Ireland. Youth and Policy, 102, 7-18.

Hilton, M. and MacKay, J. (Eds.) (2011). Ages of voluntarism: How we got to the big society. Oxford: Oxford University Press.

HMG (2012). Positive for youth: A new approach to cross-government policy for young people aged 13 to 19. London: Her Majesty’s Government.

HMT and DSCF (2007). Aiming high for young people: A ten year strategy for positive activities. London: Her Majesty’s Treasury and the Department for Schools, Children and Families.

Hopkins, P. (2007). Global events, national politics, local lives: young Muslim men in Scotland. Environment and Planning A, 39, 1119-1133.

Ignatieff, M. (1995). Blood and belonging: Journeys into the new nationalism. London: Vintage.

Jeffs, T. and Smith, M. (2010). Youth work and practice. London: Palgrave Macmillan.

Johnes, M. (2012). Wales since 1939. Manchester: Manchester University Press.

Jones, R. (2008). Relocating nationalism: on the geographies of reproducing nations. Transactions of the Institute of British Geographers, 33, 319-34.

Jones, R. and Desforges, L. (2003). Localities and the reproduction of Welsh nationalism. Political Geography, 22, 271-92.

Jones, R. and Fowler, C. (2007). Where is Wales? Narrating the territories and borders of the Welsh nation. Regional Studies, 41, 89-101.

Jones, R. and Fowler, C. (2008). Placing the nation: Aberystwyth and the reproduction of Welsh nationalism. Cardiff: University of Wales Press. 
Jones, R. and Merriman, P. (2009). Hot, banal and everyday nationalism: bilingual roadsigns in Wales. Political Geography, 28, 164-73.

Jones, W.M. (2010). Wyn Mel: Y fi a Mistar Urdd a'r cwmni da. Talybont: Gwasg y Lolfa.

Kadish, S. (1995) A good Jew and a good Englishman: The Jewish Lads' and Girls' Brigade 1895-1995. London: Valentine Mitchell.

Kearns, A. (1995). Active citizenship and local governance: political and geographical dimensions. Political Geography, 14, 155-75.

Kyle, R. G. (2007). Moral geographies of The Boys’ Brigade in Scotland. Unpublished PhD Thesis, University of Glasgow.

Laqueur, W. (1962). Young Germany: A history of the German youth movement. New York: Basic Books.

Lewis, S. (1962). Tynged yr iaith/The fate of the language. Cardiff: BBC.

Loeffler, M. (2006). “Foundations of a nation”: The Welsh League of Youth and Wales before the Second World War. Welsh History Review, 23, 110-49.

Matless, D. (1995). The Art of Right Living: landscape and citizenship, 1918-39. In N. Thrift and S. Pile (Eds.) Mapping the subject: Geographies of cultural transformation (93-122). London: Routledge

Matless, D. (1998). Landscape and Englishness. London: Reaktion Books.

Merriman, P. (2005) "Respect the life of the countryside”: the Country Code, government, and the conduct of visitors to the countryside in post-war England and Wales. Transactions of the Institute of British Geographers, 30(3), 336-350.

Mills, S. (2011a). Scouting for girls? Gender and the Scout Movement in Britain. Gender, Place and Culture, 18, 537-556. 
Mills, S. (2011b). Be prepared: Communism and the politics of Scouting in 1950s Britain. Contemporary British History, 25, 429-450.

Mills, S. (2012). Duty to God/my Dharma/Allah/Waheguru: Diverse youthful religiosities and the politics and performance of informal worship. Social and Cultural Geography, 13, 481-499.

Mills, S. (2013). “An instruction in good citizenship”: Scouting and the historical geographies of citizenship education. Transactions of the Institute of British Geographers, 38, 120-34.

Mills, S. (2014, onlinefirst). Geographies of education, volunteering and the lifecourse: the Woodcraft Folk in Britain (1925-1975). Cultural Geographies.

Paasi A. (1996). Territories, boundaries and consciousness: The changing geographies of the Finnish-Russian border. Chichester: John Wiley.

Phillips, D. (2005). The history of the Welsh Language Society. Cardiff: Welsh Academic Press.

Phillips, R. (1997). Mapping men and empire: A geography of adventure. London: Routledge.

Philo, C. and Smith, F.M. (2003). Guest editorial: political geographies of children and young people. Space and Polity, 7, 99-115.

Proctor, T.M. (2002). On my honour: Guides and Scouts in interwar Britain. Philadelphia, PA: American Philosophical Society.

Proctor, T.M. (2009). Scouting for girls: A century of Girl Guides and Girl Scouts. Santa Barbara, CA; Denver, CO; Oxford: Praeger.

Prynn, D. (1983). The Woodcraft Folk and the Labour Movement 1925-70. Journal of Contemporary History, 18, 79-95. 
Scottish Executive (2007). Moving forward: A strategy for improving young people's chances through youth work. Edinburgh: Scottish Executive.

Scourfield, J. and Davies, A. (2005). Children's accounts of Wales as racialised and inclusive. Ethnicities, 5, 83-107.

Scourfield, J., Dicks, B. Drakeford, M. and Davies, A. (2006). Children, place and identity: Nation and locality in middle childhood. London: Routledge.

Skelton, T. (2013). Young people, children, politics and space: a decade of youthful political geography scholarship 2003-2013. Space and Polity, 17, 123-136.

Smith, D. (1984). Wales! Wales? London: Allen and Unwin.

Springhall, J. (1977). Youth, empire and society: British youth movements 1883-1940. Beckenham: Croom Helm.

Stachura, P. (1981). The German youth movement 1900-1945: An interpretive and documentary history. London: Macmillan.

Stephens, S. (1997). Children and nationalism. Childhood, 4, 1-17.

Tebbutt, M. (2012). Being boys: Youth, leisure and identity in the inter-war years. Manchester: Manchester University Press.

Tilly, C.A. (Ed.) (1975). The formation of national states in Western Europe. Princeton, NJ: Princeton University Press.

Valentine, G., Sporton, D. and Nielsen K-B (2008). Language use on the move: sites of encounter, identities and belonging. Transactions of the Institute of British Geographers, 33, 376-387.

Vallory, E. (2012). World Scouting: Educating for global citizenship. Basingstoke: Palgrave Macmillan.

WAG (2007). Young people, youth work, youth service: National youth service strategy for Wales. Cardiff: Welsh Assembly Government. 
Warren, A. (1986). Sir Robert Baden-Powell, the Scout movement, and citizen training in Britain, 1900-1920. English Historical Review, 101, 376-398.

Wilkinson, P. (1969). English youth movements 1908-1930. Journal of Contemporary History, 4, 3-23.

Youth Work in Wales Review Group (2013). Youth work in Wales: Principles and purposes. Cardiff: Council for Wales of Voluntary Youth Services.

Youthlink Scotland (2011). Championing Scotland's young people: Youthlink Scotland's manifesto for the 2011 Scottish Parliament elections. Edinburgh: Youthlink Scotland.

Zhao, S. (1998). A state-led nationalism: The patriotic education campaign in postTiananmen China. Communist and Post-Communist Studies, 31, 287-302.

\footnotetext{
${ }^{1}$ Islwyn Ffowc Elis (no date) 'A tribute to the Urdd', National Library of Wales (NLW) L15, Assorted printed material.

2 Letter from Basil Davies to Miss Gwennant Davies, 26 August 1957, NLW A1989/20 I6.

${ }^{3}$ Urdd Gobaith Cymru (1950) Y Pedwerydd Adroddiad Blynyddol ar Bymtheg ynghyd â'r Cyfrifon am y flwyddyn Ebrill 1af, 1949 - Mawrth 31ain 1950 (Urdd Gobaith Cymru, Aberystwyth) p.10, NLW A11.

${ }^{4}$ Letter from Basil Davies, 1957, op cit.

${ }^{5}$ Programme of a service during which a new chapel was dedicated at the Llangrannog Camp, 13 August 1957, NLW A1989/20 I6

${ }^{6}$ Script from a play performed at Llangrannog summer camp in 1940/41, NLW I42.

${ }^{7}$ Urdd Gobaith Cymru (no date) Adroddiad a thystiolaeth Comisiwn Bywyd a Gwaith Urdd Gobaith Cymru, p. 1, NLW L13.

${ }^{8}$ Letter from Miss G. Davies to Mr. I.E. Jones, Porthcawl, 6 June 1955, NLW A 1989/30 I4.

9 NLW A1989/20 I6, Letter from Miss Gwennant Davies, Urdd Gobaith Cymru, to Miss M Jones, Maesteg Grammar School, 11 November 1957; NLW A1989/20 IS, Letter from Miss M Jones, Maesteg Grammar School to Miss Gwennant Davies, Urdd Gobaith Cymru, 25 November 1957.

${ }^{10}$ R. Alun Evans (no date) Written evidence submitted to the Commission on the Life and Work of the Urdd, Adroddiad a thystiolaeth Comisiwn Bywyd a Gwaith Urdd Gobaith Cymru, NLW L13, original emphases.

11 Cwmni Urdd Gobaith Cymru (1951) Yr Ugeinfed Adroddiad Blynyddol Ynghyd â'r Cyfrifon am y Flwyddyn, Ebrill 1af 1950-Mawrth 31ain 1951 (UGC, Aberystwyth), NLW, LL5 Assorted printed material.
} 